\title{
MICROPROPAGATION \\ OF PLANTAGO ASIATICA L. THROUGH CULTURE OF SHOOT-TIPS
}

\author{
JoANNA MAKOWCZYŃSKA, EMILIA ANDRZEJEWSKA-GOLEC \\ Department of Biology and Pharmaceutical Botany \\ Medical University of Lodz \\ Muszynskiego 1, 90-151 Lodz, Poland \\ e-mail: e.andrzejewska@wp.pl
}

(Received: September 18, 2002. Accepted: March 27, 2003)

\begin{abstract}
Shoot-tip multiplication of the medicinal species - Plantago asiatica was carried on MS medium with IAA and BAP or kinetin. Best results in micropropagation were achieved by adding $0.1 \mathrm{mg} / \mathrm{dm}^{3}$ IAA and $1 \mathrm{mg} / \mathrm{dm}^{3}$ BAP. After 6 weeks shoots were transferred to MS medium for rooting. The resulting plantlets were transferred after 8 weeks into pots and after a period of adaptation into the ground (field culture).

The species Plantago asiatica was propagated in vitro by shoot-tip multiplication for the first time.
\end{abstract}

KEY WORDS: Plantago asiatica, in vitro propagation, shoot-tip culture.

\section{INTRODUCTION}

Among over 200 described species of the Plantaginaceae family only several have been cultured in vitro so far: $P$. asiatica L. (Tu Yisheng 1996; Andrzejewska-Golec 1998a, b; Makowczyńska and Andrzejewska-Golec 2000), P. lanceolata L. (Skrzypczak et al. 1995; Budzianowska and Skrzypczak 1998; Fons et. al. 1998, 1999; Budzianowska 2001), P. major L. (Brimer 1988; Martin-Cordero et al. 1996; Mederos et al. 1997/1998), P. maritima L. (Chang and Locy 1996), P. media (Kunvari - unpublished data), $P$. ovata Forsk. (Wakhlu and Barna 1988, 1989; Pramanik et al. 1994-1996; Chowdhury et al. 1996; Barna and Wakhlu 1998).

$P$. asiatica - species related to P. major - grows only in the Far East countries (Yamazaki 1993; Rønsted 2002. Ph. D. thesis) and has been used for medicinal purposes since ancient times in the area of its occurrence (AndrzejewskaGolec 1994). P. asiatica (Plantaginis herba and Plantaginis semen) are included in the Japanese Pharmacopoeia XIV (2001). Recently this species has also been used in the food industry (Kanamaru 1994; Tokumaru and Tokumaru 1999) and cosmetics production (Ito 1996).

Multiplication of Asiatic plantain for the first time was described by Tu Yisheng (1996). He regenerated this species through indirect organogenesis and published his results in Chinese (with only English abstract).

The aim of this work is micropropagation of $P$. asiatica by use of shoot-tip culture.

\section{MATERIAL AND METHODS}

The seeds of $P$. asiatica were obtained from the Botanical Gardens, Faculty of Science, University of Tokyo. They were surface-sterilized by immersion in $2.0 \%$ sodium hypochlorite for $10 \mathrm{~min}$ and then rinsed 3 times in sterile water. Then they were germinated in aseptic conditions on Murashige and Skoog medium (MS) supplemented with $2.0 \mathrm{mg} / \mathrm{dm}^{3}$ kinetin, $1 \mathrm{mg} / \mathrm{dm}^{3}$ gibberellic acid $\left(\mathrm{GA}_{3}\right)$ and $0.7 \%$ Difco Bacto-Agar. The cultures were placed in the dark, and transferred into light after germination. The source of the explants were 2- and 4-week seedlings, from which $1 \mathrm{~cm}$ fragments of the shoot-tip were taken (Fig. 1). The explants were placed on the MS medium containing: 1 or $0.1 \mathrm{mg} / \mathrm{dm}^{3}$ of indole -3 -acetic acid (IAA) and different concentration of kinetin or 6-benzyloaminopurine (BAP) (Table 1).

In all the experiments described below, the $\mathrm{pH}$ of the media was adjusted to 5.6-5.9 and 0.7\% agar was added before autoclaving. All the media were autoclaved for 17 $\min$ at $123 \pm 2{ }^{\circ} \mathrm{C}$. All cultures were done in growing chamber at $25 \pm 2{ }^{\circ} \mathrm{C}$, in $80-90 \%$ humidity and light intensity 40 $\mu \mathrm{mol} / \mathrm{m}^{2} \mathrm{~s}$.

The resulting shoots were transferred after six weeks for rooting onto an agar MS medium without growth regulators. After a rooting period of two weeks the plantlets were washed in sterile water to remove agar and transferred into pots with a sterilized $(0.5 \mathrm{~h})$ mixture of soil, sand and peat $(3: 4: 4 \mathrm{v} / \mathrm{v})$. 

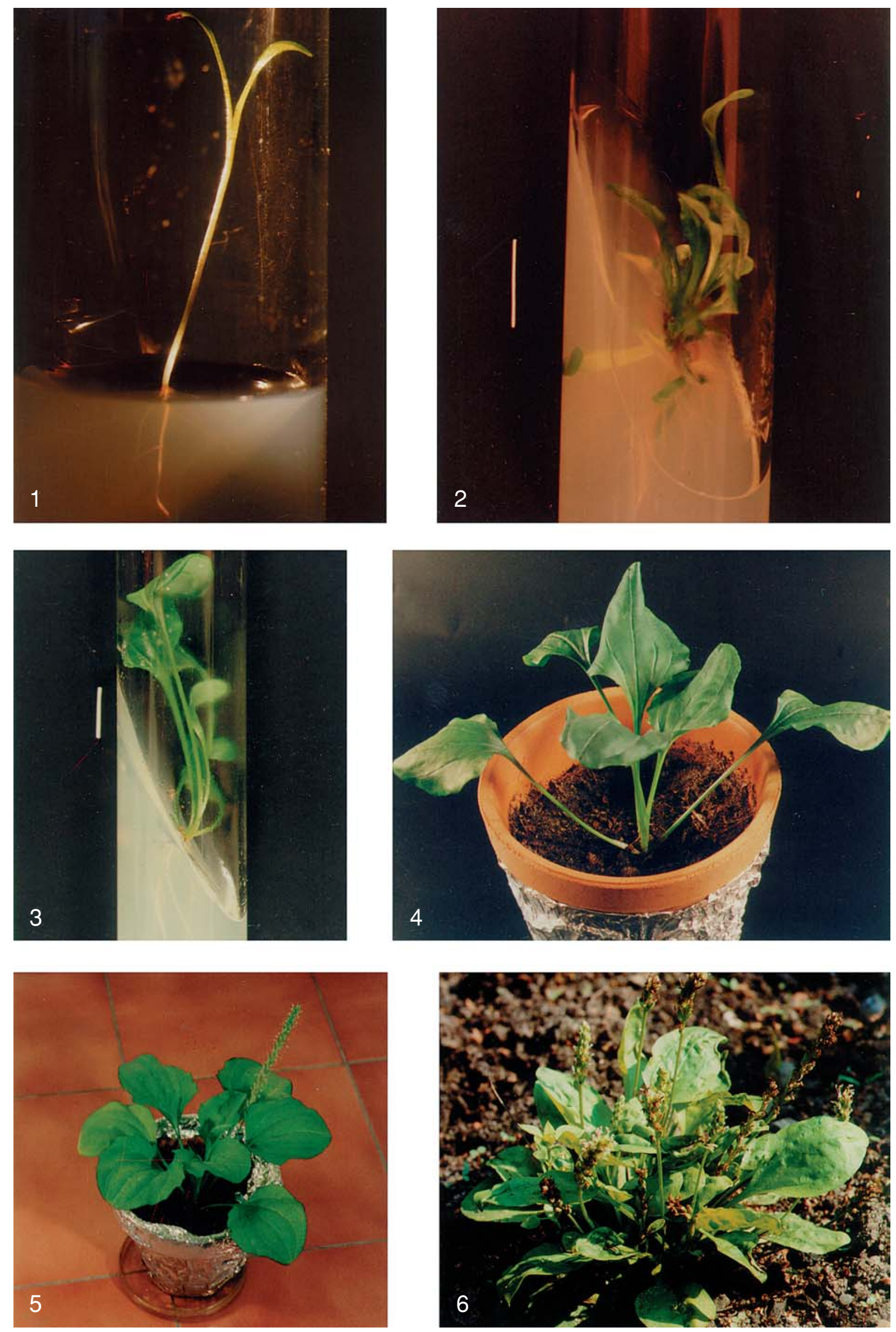

Figs 1-6. Plantago asiatica $\mathrm{L}$. - in vitro regeneration via shoot-tip method.

Fig. 1. 4-week-old seeding - the source of the explants. MS medium with $2 \mathrm{mg} / \mathrm{dm}^{3}$ kinetin and $1 \mathrm{mg} / \mathrm{dm}^{3} \mathrm{GA}_{3}$. Bar $1 \mathrm{~cm}$. Fig. 2. 4-week-old shoot. MS medium with $1 \mathrm{mg} / \mathrm{dm}^{3}$ IAA and $2 \mathrm{mg} / \mathrm{dm}^{3}$ kinetin. Bar $1 \mathrm{~cm}$. Fig. 3. 6-week-old plantlets. MS medium without growth regulators, rooting. Bar $1 \mathrm{~cm}$. Fig. 4 . 8 -week pot culture. $\times 0.55$. Fig. 5. 3-month pot culture. $\times 0.2$. Fig. 6. 5-month field culture. $\times 0.5$ (Photo: Ryszard Sąsiadek). 
TABLE 1. Micropropagation of Plantago asiatica L. through culture of shoot-tips MS medium, 6-weeks culture.

\begin{tabular}{|c|c|c|c|c|}
\hline IAA $\mathrm{mg} / \mathrm{dm}^{3}$ & Kinetin & $\mathrm{BAP} \mathrm{mg} / \mathrm{dm}^{3}$ & Number of explants & $\mathrm{MR}^{*} \pm \mathrm{SD}$ \\
\hline \multirow{3}{*}{0.1} & \multirow{3}{*}{-} & 1 & 33 & $5.18 \pm 0.58$ \\
\hline & & 2 & 32 & $4.41 \pm 0.56$ \\
\hline & & 5 & 32 & $3.23 \pm 0.53$ \\
\hline \multirow{5}{*}{1} & \multirow{3}{*}{-} & 1 & 16 & $2.25 \pm 0.72$ \\
\hline & & 2 & 35 & $4.57 \pm 0.71$ \\
\hline & & 5 & 16 & $3.31 \pm 0.80$ \\
\hline & 1 & - & 23 & $3.48 \pm 0.80$ \\
\hline & 2 & - & 35 & $2.17 \pm 0.72$ \\
\hline
\end{tabular}

MR* - multiplication rat was evaluated as the mean number of buds and shoots obtained is one explant at the end of the multiplication cycle (6 weeks).

The plants were watered every two days with sterile water. Glass covers were used to ensure high humidity around the plants at the initial steps of growth. After one week the time of contact with non-sterile air was increasing gradually. Three weeks later the glass covers were removed and the plants were watered with normal tap water. Following adaptation the plants were transferred into the ground in the Garden of Medicinal Plants, Department of Pharmacognosy, Medical University of Łódź.

\section{RESULTS AND DISCUSSION}

At the beginning of the second week of shoot-tip culture in vitro roots started to appear, and at the end of the second week the first buds appeared. The age of the seedlings ( 2 or 4 week), from which explants were sampled, did not affect their ability to form shoots or roots. The culture was continued for six weeks (Fig. 2). The best micropropagation (multiplication rate) results were obtained for MS medium enriched with $0.1 \mathrm{mg} / \mathrm{dm}^{3}$ IAA and $1 \mathrm{mg} / \mathrm{dm}^{3}$ BAP.

The plants did not require any additional media for elongation (Fig. 3). After eight weeks well-rooted plants were obtained, which were able to develop further in pot culture. In the eighth week of culture in pots the plants formed basal rosettes consisting of 6-7 leaves, each 10-12 cm long (Fig. 4)

Plants derived from in vitro clonal propagation by shoottip multiplication were normal in appearance. They did not significantly differ in morphology from the plants obtained in our climate during conventional culture in the soil. Only the colour of the first leaves in plants obtained by the micropropagation of shoot-tips was intensively dark green. The next leaves were the usual bright green colour. The plants showed good vigour. They developed a normal root system. Plant cultures in vitro blossomed between the $3 \mathrm{rd}$ and 5th months of the pot culture (Fig. 5). In room conditions they gave fruit and normal fertile seeds. The plants were transplanted into the soil (field culture) and survived winter well (Fig. 6).

The advantage of the method used: micropropagation of the plants through culture shoot-tips is the utilisation of meristems which are already present in explants. In this way plants of exactly the same genotype and phenotype as the mother plant can be obtained. This method is commonly employed in in vitro cultures of therapeutic and decorative plants. Pramanik et al. (1995), using shoot-tip multipli- cation regenerated another species from the Plantaginaceae family $-P$. ovata with the best multiplication effect obtained with MS medium enriched with $0.2 \mathrm{mg} / \mathrm{dm}^{3}$ of IAA and $5 \mathrm{mg} / \mathrm{dm}^{3}$ BAP.

Mederos et al. (1997/1998) regenerated in this way $P$. major. This species is related to $P$. asiatica (Rahn 1996). $P$. major and $P$. asiatica differ in the range of distribution, morphological characteristics (presence of flower stalk, size of the seeds and number of the seeds per one capsule), chemical composition of iridoids, phenylethanoids and flavonoids and chromosome number (Yamazaki 1993, Taikun et al. 1994, Nishibe and Murai 1995). Mederos et al. (1997/1998) used modified MS medium (reduction of the $\mathrm{NH}_{4} \mathrm{NO}_{3}$ and $\mathrm{KH}_{2} \mathrm{PO}_{4}$ contents) to shoot-tip culture. This author achieved best results of micropropagation by adding $50 \mathrm{~g} / \mathrm{dm}^{3}$ glucose and $0.1 \mathrm{mg} / \mathrm{dm}^{3}$ BAP to the medium.

It is the first publication of $P$. asiatica regeneration by shoot-tip method. Results of our preliminary investigations of this plant by shoot-tip multiplication were presented earlier (Makowczyńska and Andrzejewska 1998).

\section{ACKNOWLEDGEMENTS}

The work is financed by the fund Medical University of Lodz, No. 502-13-675.

\section{LITERATURE CITED}

ANDRZEJEWSKA-GOLEC E. 1994. Babkowate (Plantaginaceae) - rośliny lecznicze. Farm. Pol. 50: 899-905.

ANDRZEJEWSKA-GOLEC E. 1998 a. Somatyczna organogeneza w kulturach tkankowych Plantago asiatica L. (Somatic organogenesis in tissue culture of Plantago asiatica L.) In: Botanika polska u progu XXI wieku. Mat. sympozjum i obrad sekcji 51. Zjazdu PTB. Miądlikowska J. (ed.) Gdańsk, p. 10. (in Polish)

ANDRZEJEWSKA-GOLEC E. 1998 b. Namnażanie Plantago asiatica $\mathrm{L}$. $\mathrm{z}$ blaszek i ogonków liściowych w hodowli in vitro. In: Farmacja w perspektywie XXI wieku. XVII Naukowy Zjazd PTF. Streszczenia. Filipek B., Librowski T., SchegelZawadzka M. (eds). Kraków, p. 279. (in Polish)

BARNA K. S., WAKHLU A. K. 1988. Axillary shoot induction and plant regeneration in Plantago ovata Forsk. Plant Cell Tiss. Organ Cult. 15: 169-173.

BRIMER L. 1988. Production of plantamajoside and verbascoside in suspension cell cultures of Plantago major. In - Vitro. 24: 3 , abstract. 
BUDZIANOWSKA A. 2001. Tkanka kalusowa Plantago lanceolata L. i jej analizy fitochemiczne. (Callus cultures of Plantago lanceolata L. and its fitochemical analysis.) In: Botanika w dobie biologii molekularnej. Mat. sesji i sympozjów 52. Zjazdu PTB. Zenkteler E. (ed.) Poznań, p. 160. (in Polish)

BUDZIANOWSKA A., SKRZYPCZAK L. 1998. Wstępna analiza związków fenolowych Plantago lanceolata L. ze stanowisk naturalnych i kultur in vitro. In: Botanika polska u progu XXI wieku. Mat. sympozjum i obrad sekcji 51. Zjazdu PTB. Miądlikowska J. (ed.) Gdańsk, p. 65. (in Polish)

CHANG I.D., LOCY R.D. 1996. In vitro regeneration of plants of the haplotype Plantago maritima L. from primary explants and callus cultures. In - Vitro 32: 3, abstract.

CHOWDHURY A.R., KUNDU S., RAYCHUDHURI S.S. 1996. Regeneration of Plantago ovata Forsk. through somatic embryogenesis. Cytobios 85: 255-261.

FONS F., GARGADENNE C. A., GUEIFFIER A., ROUSSEL J.L., ANDARY C. 1998. Effects of cinnamic acid an polyphenol production in Plantago lanceolata. Phytochemistry 49: 697-702.

FONS F., TOUSCH D., RAPIOR S., GUEIFFIER A., ROUSSEL J.L., GARGADENNE C.A., ANDARY C. 1999. Phenolic profiles of untransformed and hairy root cultures Plantago lanceolata. Plant Physiol. Biochem. 37: 291-296.

ITO M. 1996. Hair tonic and growth stimulant compositions containing testosterone $5 \alpha$-reductase inhibitors extracted from plants. Jpn Kokai Tokyo Koho JP 083011730 A2 19, Nov 1996 (Japan). C.A.126: 108633, 1997.

KANAMARU M. 1994. Health pet food. Jpn Kokai Tokyo Koho IP 08, 191, 668[96, 191, 668] 30 Jul 1996 (Japan); C.A. 125: $194148,1996$.

MAKOWCZYŃSKA J. ANDRZEJEWSKA-GOLEC E. 1998. Mikropropagacja Plantago asiatica metodą hodowli wierzchołków pędów. In: Botanika polska u progu XXI wieku. Mat.sympozjum i obrad sekcji 51. Zjazdu PTB. Miądlikowska J. (ed.). Gdańsk, p. 306.

MAKOWCZYŃSKA J. ANDRZEJEWSKA-GOLEC E. 2000. Somatic embryogenesis in in vitro culture of Plantago asiatica L. Acta Soc. Bot. Pol. 69: 245-250.

MARTIN-CORDERO C., MEDEROS S., NAVARRO E., AYUSO M.J. 1996. Evaluation of Plantago in situ and in vitro for cytotoxic activity. Exp. Clinic. Pharmacol. 18: 144.

MEDEROS S., MARTIN C., NAVARRO E., AYUSO M.J. 1997/98. Micropropagation of a medicinal plant, Plantago major L. Biol. Plant. 40: 465-468.
NISHIBE S., MURAI M. 1995. Bioactive Components of Plantago Herb. FFI Journal 166: 43-49.

PRAMANIK S., CHAKRABORTY S., RAYCHAUDHURI S.S. 1994. Nuclear DNA content and chromosomal variation in relation to callus growth during in vitro regeneration in Plantago ovata. Cytobios 80: 101-108.

PRAMANIK S., CHAKRABORTY S., RAYCHAUDHURI S.S. 1995. In vitro clonal propagation and characterization of clonal regenerants of Plantago ovata Forsk. by isozyme analysis. Cytobios 82: 123-130.

PRAMANIK S., RAYCHAUDHURI S.S., CHAKRABORTY S. 1996. Changes in esterase and superoxide dismutase isozymes during in vitro morphogenesis in Plantago ovata Forsk. Plant Cell Tiss. Organ Cult. 44: 123-127.

RAHN K. 1996. A phylogenetic study of the Plantaginaceae. Bot. J. Linn. Soc. 120: 145-198.

RØNSTED N. 2002. Towards a natural classification of Plantago. Chemical and molecular systematics. Ph. D. thesis Royal Danish School of Pharmacy, Depart. of Medicinal Chemistry. Copenhagen.

SKRZYPCZAK L., THIEM B., WESOŁOWSKA M. 1995. Kultury in vitro roślin źródłem związków biologicznie czynnych. In: Szata roślinna Polski w procesie przemian. Mat. konferencji i sympozjów 50. Zjazdu PTB. Mirek Z., Wójcicki J.J. (eds). Kraków, p. 368. (in Polish)

TAIKUN Z., TANAKA T., HISHIKAWA K., NORO Y., HISATA Y., YOSHIDA M., SAKAI E. 1994. Pharmaceutical Studies of Plantaginis Herba. Morphological and Histological Studies on the Seeds of Chinese Plantago sp. Nat. Med. 48: 63-70.

TOKUMARU S., TOKUMARU K. 1999. Fermented milk produced - based health food. Jpn. Kokai Tokyo Koho IP 11089512 A 26 Apr. 1999. CA 130: 251566, 1999.

TU YISHENG. 1996. Tissue culture of asiatic plantain (Plantago asiatica). Zhongcaoyao 27: 296. (in Chinese)

WAHLU A.K., BARNA K.S. 1988. Chromosome studies in hypocotyl callus cultures and regenerated plants of Plantago ovata Forsk. The Nucleus 13: 14-17.

WAHLU A.K., BARNA K.S. 1989. Callus initiation, growth and plant regeneration in Plantago ovata Forsk. Plant Cell Tiss. Organ Cult. 17: 235-241.

YAMAZAKI T. 1993. Plantaginaceae. In: Flora of Japan. Iwatsuki K. et al. (eds). Kodansha LTD, Tokyo, Vol. 3a, pp. 184$-186$.

\title{
MIKROPROPAGACJA PLANTAGO ASIATICA L. NA DRODZE HODOWLI WIERZCHOŁKÓW PĘDÓW
}

\author{
STRESZCZENIE
}

\begin{abstract}
Namnażanie babki azjatyckiej poprzez hodowlę wierzchołków pędów przeprowadzono na podłożu MS wzbogaconym IAA i BAP lub kinetyną. Najlepsze wyniki uzyskano stosując $0,1 \mathrm{mg} / \mathrm{dm}^{3}$ IAA i $1 \mathrm{mg} / \mathrm{dm}^{3}$ BAP. Po 6-tygodniowej hodowli pędy przenoszono na podłoże $0,5 \mathrm{MS}$ bez regulatorów wzrostu w celu ukorzenienia. Uzyskane po 8 tygodniach roślinki przenoszono do doniczek a po aklimatyzacji do gleby.

Dla gatunku $P$. asiatica opracowano metodę mnożenia in vitro poprzez hodowlę wierzchołków pędów. Autorki uzyskały babkę azjatycką metodą hodowli wierzchołków pędów po raz pierwszy.
\end{abstract}

SŁOWA KLUCZOWE: Plantago asiatica, mnożenie in vitro, hodowla wierzchołków pędów. 